\title{
NECESSITY OF MAPPING AND ASSESSMENT OF ECOSYSTEMS AND THEIR SERVICES IN PLANNING AND DECISION MAKING PROCESS
}

\author{
Līga Brūniņa \\ Association Baltic Coasts, Latvia \\ Elīna Konstantinova \\ Ventspils University College, Latvia \\ Aija Peršēvica \\ Association Baltic Coasts, Latvia
}

\begin{abstract}
The EU Biodiversity Strategy to 2020 determines that "Member States, with the assistance of the Commission, will map and assess the state of ecosystems and their services in their national territory by 2014, assess the economic value of such services, and promote the integration of these values into accounting and reporting systems at EU and national level by 2020". Mapping and assessment of ecosystem services provides several benefits, one of which is baseline data providing to measure net future gains or losses and data integration into spatial development process.

The aim of the paper is to present and discuss the approach taken to assessing ecosystem services in order to introduce necessity of mapping and assessment of ecosystems and their services for planning and decision-making process in Latvia. The paper will focus on terminology interpretation of ecosystem services, introducing with set of developed indicators for assessment of ecosystem services and define appropriate for Latvia. The paper closes with estimation of potential benefits and necessity to integrate assessment of ecosystems services in spatial planning and decision-making process.
\end{abstract}

Keywords: ecosystem services, ecosystem services assessment, land use planning and management, decision making.

\section{Introduction}

Ecosystems as a research topic are relatively new. Only in year 1935 A.Tansley (Tansley, 1935) introduced the concept of the ecosystem. Since that time researches of ecosystems and their services in Europe have been rapidly developed (Seppelt et al., 2011).

Assessment of ecosystem services has been set a strategically important role at the European Union countries, including it to the EU Biodiversity Strategy to 2020. EU Biodiversity Strategy determines that "Member States, with the assistance of the Commission, will map and assess the state of ecosystems and their services in their national territory by 2014, assess the 
economic value of such services, and promote the integration of these values into accounting and reporting systems at EU and national level by 2020" (EU, 2011).

The growing attention of science and practice to ecosystem services has led to an increased interest in both the public and private sectors for approaches to develop and apply ecosystem services indicators in real-world decision-making (Daily et al., 2009). Several decision support systems are evolving for integrating ecosystem approach into planning processes (Bagstad et al., 2013), i.e., interactive, computer-based tools, which help decision makers to visualize, compare, and consider trade-offs among many ecological, social, and economic values (Labiosa et al., 2013). Although a lot of these systems already provide helpful functionalities, they are not integrated into everyday decision-making yet, because they do not readily fit into existing planning processes (Bagstad et al., 2013).

In the context of Latvia the concept of ecosystems and their services and researches of ecosystem services are relatively new. Assessment of ecosystem services in Latvia was started within several EU supported projects, for example LIFE "Assessment of ecosystems and their services for nature biodiversity conservation and management" (EcosystemServices), LIFE "Integrated planning tool to ensure viability of grasslands" (LIFE Viva Grass), LIFE "Alternative use of biomass for maintenance of grassland biodiversity and ecosystem services" (LIFE Grasservice).

The paper focuses on ecosystems approach from decision making perspective. The paper addresses three research questions: (i) What is the background of ecosystem services assessment integration into decision making processes? (ii) How could ecosystems and their services can be estimated and assessed? (iii) How could ecosystem approach be integrated in decision making processes of land use planning and management? The first research question could be studied by revisiting and analysing the relevant EU policy strategies and scientific literature on ecosystem approach, ecosystem services assessment and their relation with decision making. The second research question is answered by analysing of case study for Latvian coastal ecosystems and applying expert method for identifying appropriate ecosystem services. For ecosystem approach integration into decision making processes the existing case studies has been analysed and conceptual framework model proposed.

\section{The ecosystem approach and decision making processes in EU and Latvia}

The concept of an ecosystem provides a valuable framework for analyzing and acting on the linkages between people and their environment. For that reason the Ecosystem Approach has been endorsed by the Convention on 
Biological Diversity (CBD) and the Millennium Ecosystem Assessment (MA). The Ecosystem Approach is a strategy for the integrated management of land, water and living resources that promotes conservation and sustainable use in an equitable way.

The concept of ecosystem services has been defined as benefits people receive from ecosystems (MA, 2005). Ecosystem services are defined as goods and services provided by ecosystems which contribute to human well-being, ranging from provisioning (e.g., food, fresh water) and regulating (e.g., water, climate regulation) to cultural (e.g., recreational experiences) and supporting services (e.g., habitat for plant and animal species) (MA, 2005; de Groot et al., 2010).

Currently ecosystem services are studied much more closely in the context of man and his action, emphasizing that ecosystem services are related to human actions, decisions and investments (Burkhard et al., 2012).

In line with the Millennium Ecosystem assessment, the objective of the ecosystem services assessment is to provide a critical evaluation of the best available information for guiding decisions on complex public issues. The work being carried out is important for the advancement of biodiversity objectives, and also to inform development and implementation of related policies on water, climate, agriculture, forest, and regional planning. Robust, reliable and comparable data are also important for strategic and land use planning (MA, 2005). The assessment of ecosystem services can provide information to decision makers not only about the state and trends of ecosystem services (Fitter et al., 2010; Maes et al., 2012), but also identify spatial dependencies and tradeoffs (Terrado et al., 2014).

Although several planning documents anticipate ecosystem services assessment in Latvia, such researches was only recently started. One of the priorities of the National Development Plan 2020 (Saeima of the Republic of Latvia, 2012) foresees a sustainable management of nature and cultural capital, respectively, maintaining the natural capital as a basis for sustainable economic growth, promoting sustainable ways of its use, and reducing the risks for the environmental quality caused by natural and anthropogenic factors. In Latvia in order to reach these goals it is provided to carry out the assessment of the natural capital till 2030 (provided in the section „Sustainable use of the natural values and services") (Saeima of the Republic of Latvia, 2010). One of the projects to step towards reaching these strategic objectives is project LIFE EcosystemServices. 


\section{Case study: Ecosystems and their services assessment in coastal areas of Latvia}

The case study of ecosystems and their services assessment in coastal areas of Latvia is related to EU supported project "LIFE EcosystemServices" started in 2014. One of a general objective of the project is to create a clearly comprehensive ecosystems services assessment system and to promote a new methodological approach for economic evaluation of the ecosystems and their services by information and communication of the long term benefits of the economically, environmentally and socially responsible decision making and lifestyle for the increase of the overall welfare in the region.

The approach of ecosystems and ecosystem services assessment for Latvia is approbated in two coastal pilot areas - Jaunķemeri and Saulkrasti (Figure 1).
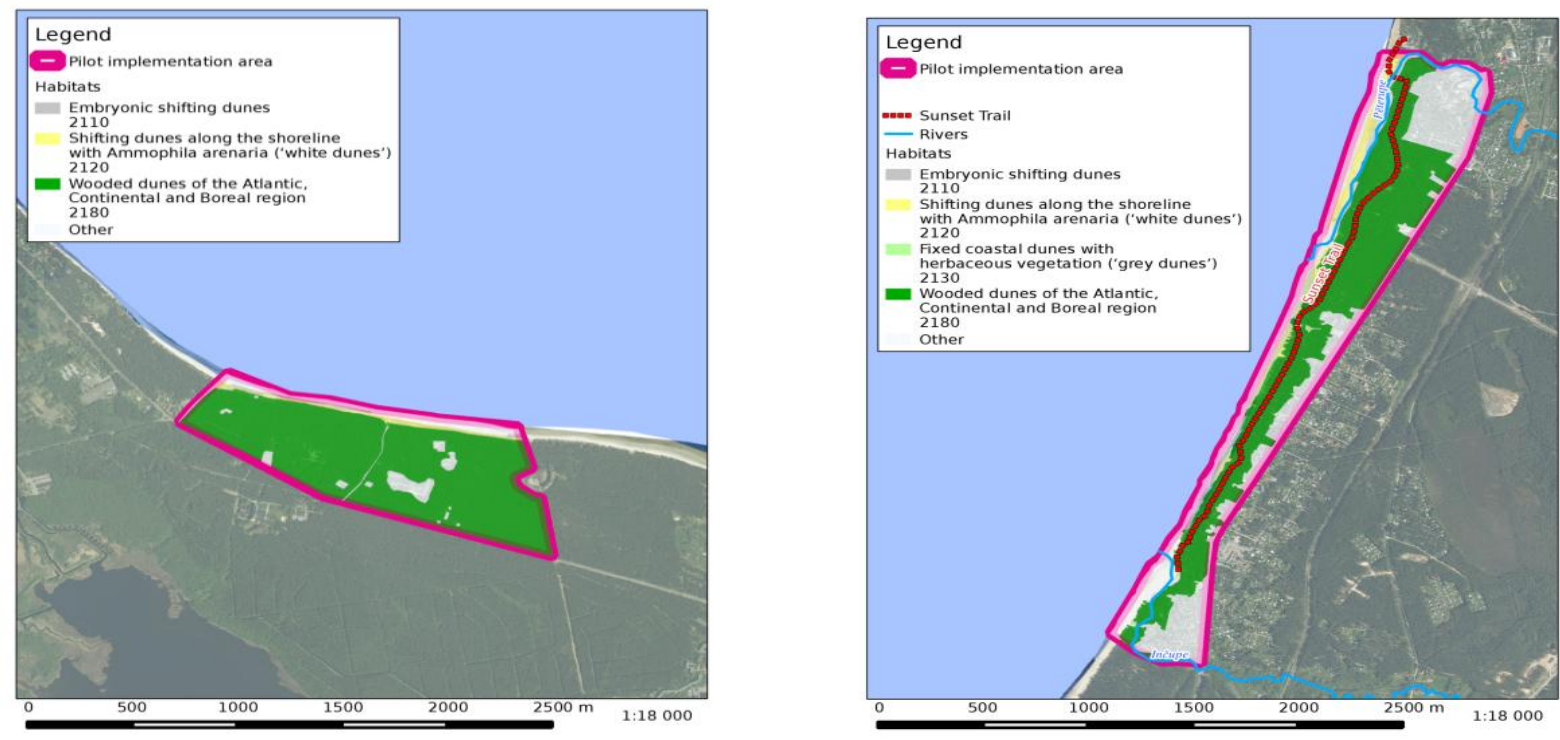

Figure 1 Ecosystems and their services assessment pilot areas. At the left side pilot area Jaunksemeri and at the right side Saulkrasti (author's construction developed within the project LIFE “EcosystemServices")

The pilot area "Jaunķemeri" is located within the city and is a part of Kemeri national park. It includes sandy beach and biologically valuable habitat of EU importance - wooden dunes. The area is not much transformed and relatively poorly visited $(90,85 \mathrm{ha})$. The pilot area "Saulkrati" is located in Saulkrasti municipality. It includes sandy beach and biologically valuable habitat of EU importance - wooden dunes and remarkable cultural and nature monument - White Dune. The well maintained nature object is frequently visited and subjected to excessive anthropogenic pressure and erosion (132,86 ha). 
The ecosystem services identification and classification is based on the Common International Classification of Ecosystem Services (CICES). To develop matrix of indicators of ecosystem services assessment for the pilot territories, expert knowledge based ecosystems services assessment method was used. Expert knowledge based ecosystem services assessment is an effective tool not only for ecosystems valuation but also to improve cooperation between scientists, experts, stakeholders and decision makers (Jacobs, 2015).

The group of experts, who developed ecosystem services matrix, consisted of 16 experts of different fields - including Geographic Information System Specialist, Public and Target group Specialist, Environmental Specialist Cultural Heritage Specialist, Architect/Landscape Expert, Hydrology Expert, Geological Expert, Species and Habitat Conservation Expert.

Ecosystem services categories, groups and classes are specified in the ecosystem services matrix (Table 1).

Table 1 Indicators of ecosystem services (author's construction based on the expert data gained within the project LIFE "EcosystemServices")

\begin{tabular}{|c|c|c|c|}
\hline Category & Department & Group & Class \\
\hline \multirow{7}{*}{$\begin{array}{l}\text { Providing } \\
\text { services }\end{array}$} & \multirow{2}{*}{$\begin{array}{c}\text { Food \& } \\
\text { Beverages }\end{array}$} & \multirow{2}{*}{ Biomass } & Wild plants, algae and their outputs \\
\hline & & & Wild fish \\
\hline & \multirow{3}{*}{ Materials } & \multirow{3}{*}{ Biomass } & $\begin{array}{l}\text { Fibres and other materials from plants, algae } \\
\text { and animals for direct use or processing }\end{array}$ \\
\hline & & & $\begin{array}{c}\text { Materials from plants, algae and animals for } \\
\text { agricultural use }\end{array}$ \\
\hline & & & Medicinal resources \\
\hline & \multirow{2}{*}{ Energy } & $\begin{array}{l}\text { Biomass-based } \\
\text { energy source }\end{array}$ & Plant based resources \\
\hline & & $\begin{array}{l}\text { Mechanical } \\
\text { energy }\end{array}$ & Sources of Abiotic energy: wind; sea waves \\
\hline \multirow{8}{*}{$\begin{array}{l}\text { Regulating } \\
\text { services }\end{array}$} & \multirow{3}{*}{$\begin{array}{c}\text { Mediation of } \\
\text { waste, toxics } \\
\text { and other } \\
\text { nuisances }\end{array}$} & \multirow{3}{*}{$\begin{array}{l}\text { Mediation by } \\
\text { ecosystems }\end{array}$} & $\begin{array}{c}\text { Filtration/sequestration/storage/ } \\
\text { accumulation by ecosystems }\end{array}$ \\
\hline & & & $\begin{array}{l}\text { Dilution by atmosphere, freshwater and } \\
\text { marine ecosystems }\end{array}$ \\
\hline & & & Mediation of smell/noise/visual impacts \\
\hline & \multirow{5}{*}{$\begin{array}{l}\text { Mediation of } \\
\text { flows }\end{array}$} & \multirow[t]{2}{*}{ Mass flows } & $\begin{array}{l}\text { Mass stabilisation and control of erosion } \\
\text { rates provision of the erosion }\end{array}$ \\
\hline & & & Buffering and attenuation of mass flows \\
\hline & & \multirow{2}{*}{ Liquid flows } & $\begin{array}{l}\text { Hydrological cycle and water flow } \\
\text { maintenance }\end{array}$ \\
\hline & & & Flood protection \\
\hline & & $\begin{array}{l}\text { Gaseous / air } \\
\text { flows }\end{array}$ & Storm protection \\
\hline
\end{tabular}


Lìga Brūniña, Elīna Konstantinova, Aija Peršēvica. Necessity of Mapping and Assessment of Ecosystems and their Services in Planning and Decision Making Process

\begin{tabular}{|c|c|c|c|}
\hline Category & Department & Group & Class \\
\hline & & Lifecycle & Pollination and seed dispersal \\
\hline & & $\begin{array}{l}\text { maintenance, } \\
\text { habitat and gene } \\
\text { pool protection }\end{array}$ & $\begin{array}{c}\text { Maintaining nursery populations and } \\
\text { habitats }\end{array}$ \\
\hline & & Pest and disease & Pest control \\
\hline & Maintenance of & control & Disease / invasive species control \\
\hline & $\begin{array}{l}\text { physical, } \\
\text { chemical, } \\
\text { biological }\end{array}$ & $\begin{array}{l}\text { Soil formation } \\
\text { and } \\
\text { composition }\end{array}$ & Decomposition and fixing processes \\
\hline & conditions & $\begin{array}{c}\text { Water } \\
\text { conditions }\end{array}$ & Chemical condition of freshwaters \\
\hline & & $\begin{array}{l}\text { Atmospheric } \\
\text { composition }\end{array}$ & $\begin{array}{l}\text { Global climate regulation by reduction of } \\
\text { greenhouse gas concentrations }\end{array}$ \\
\hline & & $\begin{array}{l}\text { and climate } \\
\text { regulation }\end{array}$ & Micro and regional climate regulation \\
\hline \multirow{7}{*}{$\begin{array}{l}\text { Cultural } \\
\text { services }\end{array}$} & \multirow{6}{*}{$\begin{array}{l}\text { Physical and } \\
\text { intellectual } \\
\text { interactions } \\
\text { with biota, } \\
\text { ecosystems, and } \\
\text { land-/seascapes }\end{array}$} & \multirow{2}{*}{$\begin{array}{l}\text { Physical and } \\
\text { experiential } \\
\text { interactions }\end{array}$} & $\begin{array}{c}\text { Experiential use of plants, animals and } \\
\text { land-/seascapes in different environmental } \\
\text { settings }\end{array}$ \\
\hline & & & $\begin{array}{c}\text { Physical use of land-/seascapes in different } \\
\text { environmental settings }\end{array}$ \\
\hline & & \multirow{4}{*}{$\begin{array}{l}\text { Intellectual and } \\
\text { representative } \\
\text { interactions }\end{array}$} & $\begin{array}{l}\text { Educational } \\
\end{array}$ \\
\hline & & & Heritage, cultural \\
\hline & & & Entertainment \\
\hline & & & Aesthetic \\
\hline & $\begin{array}{c}\text { Spiritual, } \\
\text { symbolic and } \\
\text { other } \\
\text { interactions } \\
\text { with biota, } \\
\text { ecosystems, and } \\
\text { land-/seascapes }\end{array}$ & $\begin{array}{l}\text { Spiritual and/or } \\
\text { emblematic }\end{array}$ & Symbolic \\
\hline
\end{tabular}

As the whole 3 ecosystems (dunes, woodlands, rivers), 40 ecosystem services provides by these ecosystems and 10 land cover types are identified in the pilot areas. Based on this classification the certain indicators for each service can be developed and common assessment by applying ecosystem matrix method (prepared by authors and experts within project LIFE "EcosystemServices") can be implemented.

By ecosystems services assessment in coastal areas it is possible to put forward the long-term requirements for the sustainable use and maintenance of the resources, different biotopes and their required areas, evaluating which ecosystems need protection and conservation, which require more intense maintenance, and which - restoration. 


\section{Bringing Ecosystem approach into decision making in land use planning and management}

Ecosystems services assessments can be an attractive tool for supporting decisions on land use because they can highlight benefits and trade-offs between different land-use options, ideally by integrating biophysical and socioeconomic methods (Förster et al., 2015). Therefore, ecosystems services assessments are increasingly used in decision-oriented processes, including environmental impact assessments and land-use planning for biodiversity conservation and catchment management (Förster et al., 2015). However, it is now widely recognized that nature conservation and conservation management strategies do not necessarily pose a trade-off between the "environment" and "development" but that investments in conservation, restoration and sustainable ecosystem use generate substantial ecological, social and economic benefits (de Groot et al., 2010). On the other hand, there are alarming findings, for example, that the destruction of nature has now reached levels where serious social and economic costs are being felt and will be felt at an accelerating pace if we continue with 'business as usual' (TEEB, 2010). Therefore a stronger integration of the ecosystem services concept in spatial plans could help reduce such costs and promote the generation of benefits which, traditionally, has not been considered in spatial plans.

In Latvia such practice has not been introduced yet, although in other countries the application of assessment of ecosystems and their services is widely common, and the decision making process based on the evaluation results performed on municipal, as well as national level. This results in the negative impact on the environment, caused by the lack of management strategies and evaluation approaches, particularly in areas with increased anthropogenic load. Regarding the regional and municipal spatial planning tendencies, these natural territories often fail as opposed to the commercial and business considerations. In order to explain the importance of the natural capital to the decision makers, entrepreneurs and general public, it is essential to assess both non-monetary (ecological, social, cultural) and monetary values of the ecosystems that would allow the comparison of the natural values against the socio-economic needs.

The authors of the article propose the conceptual framework for ecosystem approach integration into decision making consisting of 7 steps, which could be implemented by different national, regional and local institutions at different levels (Figure 2). 
Lìga Brūniņa, Elīna Konstantinova, Aija Peršēevica. Necessity of Mapping and Assessment of Ecosystems and their Services in Planning and Decision Making Process

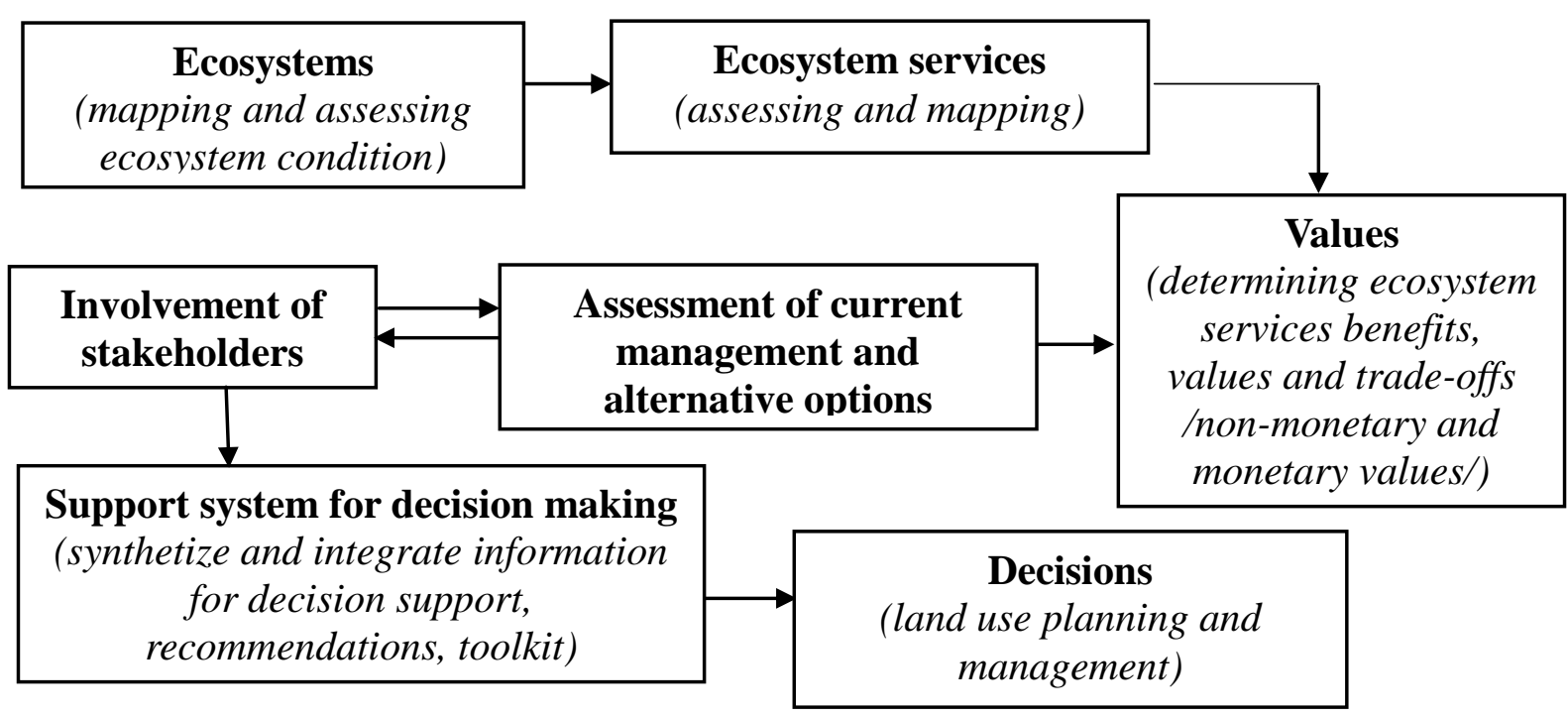

Figure 2 A framework for ecosystem approach integration into decision making (author's construction)

Mapping of ecosystems includes data identification for ecosystem mapping. Mapping of ecosystems is largely dependent on the availability of landcover/land-use datasets at various spatial resolutions. The most comprehensive dataset for terrestrial and freshwater ecosystems at EU level is Corine Land Cover (CLC). Assessing of the condition of ecosystems includes review of data and indicators for ecosystem assessment. It should make use of existing data, mainly the reported data under EU legislation and, in particular, from assessments under Art. 17 of the Habitats Directive and Art. 12 of the Birds Directive, the Water Framework Directive, the Marine Strategy Framework Directive and other environmental legislation.

To perform ecosystem services assessment, it is necessary to classify ecosystem services. Three international classification systems are available to classify ecosystem services - Millennium Ecosystem Assessment (MA), Common International Classification of Ecosystem Services (CICES) and The Economics of Ecosystems and Biodiversity (TEEB). Developed ecosystem classification systems are similar and include three primary ecosystem services providing, regulating and cultural services. Assessment can be implemented by ecosystem services matrix method by involvement of experts, comparing and analysing different indicators and applications of economic valuation methods. Cost-benefit analyses and other methodologies express apples-to-oranges comparisons in monetary currencies, making alternative options easier to compare.

Assessment provides values or beneficial outcomes (ecological, social and economical values of ecosystem services) which plays the most important role 
in decision making in land use planning and management.

Assessment of current management and alternative options. Identifying policies and management options requires understanding of the current land-use policies and practices within their socioeconomic and cultural context (Cowling et al., 2008; Ostrom, 2009; Chan et al., 2012). Within ecological limits, landscapes offer a range of potential land-use options and configurations. Social, cultural, and economic processes influence and determine ecosystem services potential, with power relations, property and access rights, investments of time, labour, and resources.

Involvement of stakeholders. Collaboration of scientists, decision makers, public and private stakeholders is the key to transform landscape patterns into more sustainable ones (Healey, 2007; Scholz, 2011). This promotes both engagement of relevant stakeholders and building of trust between stakeholder groups. Trust among stakeholders is important for sharing knowledge, but also for acknowledging relevant knowledge gaps. This includes, for example, local knowledge on diversifying crop production as means of building resilience to droughts and pests. The process of stakeholder involvement is both directed for supporting decision makings and also for reviewing and evaluating of current management and alternative options.

Support system for decision making. Basing on information obtained and assessments performed a support system for decision making should be developed which introduces new methodological approach for the planning and management of the territories by introducing ecosystem approach, which would be based in the socio-economic aspects and their potential development.

Decision making. All previously described steps result in decision making to maintain ecosystems and their services by managing the system sustainably.

\section{Conclusions}

Using a broad interpretation, in which ecosystem services benefits are based on multiple values, the ecosystem services concept can be valuable for decision support: it allows assessing human dependence on ecosystems through inter- and transdisciplinary research, integrating perspectives and values of different stakeholder groups, and guiding decisions on resource use (Förster et al., 2015).

Decision makers do not necessarily need an exhaustive understanding of the social-ecological system, but they need sufficient arguments to make a choice between land-use options. There is important to provide the framework for improvements for the strategic planning documents (Spatial Development Plans and Nature Conservation Plans) and to promote the understanding of the 
Lìga Brūniņa, Elīna Konstantinova, Aija Peršēevica. Necessity of Mapping and Assessment of Ecosystems and their Services in Planning and Decision Making Process

various stakeholder groups on the topics of sustainable planning for the enhancement of common benefits.

Although a lot of decision support systems already provide helpful functionalities, they are not integrated into everyday decision-making yet, mainly because they do not readily fit into planning processes in practice. Guidelines or recommendations for conducting such processes are still missing. Here, we are planning contribute to the development of such recommendations by means of practical case studies of the pilot areas. The focus is placed on how integration of ecosystem services assessment can be integrated into land use decision making process and practice basing on the conceptual framework presented above.

The presented framework stresses the need to: (a) identify and assess ecosystems and their services; (b) information needs by decision makers from the outset of the assessment process, and (b) focus on decision making basing on relevant ecosystem services assessment values and support system

\section{Acknowladgement}

The research underlying this manuscript has been conducted within LIFE "EcosystemServices" (LIFE13 ENV/LV/000839) project, co-financed by the European Union.

\section{References}

Bagstad, K. J., Semmens, D. J., Waage, S., \& Winthrop, R. (2013). A comparative assessment of decision-support tools for ecosystem services quantification and valuation. Ecosystem Services 5:27-39.

Burkhard, B., Kroll, F., Nedkov, S., \& Müller, F. (2012): Mapping supply, demand and budgets of ecosystem services. Ecological Indicators 21, 17-29.

Daily, G.C., Polasky, S., Goldstein, J., Kareiva, P. M., Mooney, H.A., Pejchar, L., Ricketts, T.H., Salzman, J., \& Shallenberger, R. (2009) Ecosystem services in decision making: time to deliver, Frontiers in Ecology and the Environment 7(1), 21-28

European Commission, (2011). Our life insurance, our natural capital: an EU Biodiversity Strategy to 2020. COM(2011) 244, Brussels.

Fitter, A., Elmqvist, T., Haines-Young, R., Potschin, M., Rinaldo, A., Setala, H., StollKleemann, S., Zobel, S.M., \& Murlis, J. (2010). An assessment of ecosystem servicesand biodiversity in Europe. Issues of Environmental Science and Technology, 30, 1-28.

Förster, J., Barkmann, J., Fricke, R., Hotes, S., Kleyer, M., Kobbe, S., Kübler, D., Rumbaur, C., Siegmund-Schultze, M., Seppelt, R., Settele, J., Spangenberg, J.H., Tekken, V., Václavík, T., \& Wittmer, H. (2015). Assessing ecosystem services for informing landuse decisions: a problem-oriented approach. Ecology and Society 20 (3), 31

De Groot, R.S., Alkemade, R., Braat, L., Hein, L., \& Willemen, L. (2010). Challenges in integrating the concept of ecosystem services and values in landscape planning, management and decision making Ecological Complexity, 7, 260-272 
Healey, P. (2007). Urban Complexity and Spatial Strategies. Towards a Relational Planning for Our Times. Routledge, London and New York.

Jacobs S., Burkhard, B., Van Daele, T., Staes, J., \& Schneiders, A., (2015) 'The Matrix Reloaded' - A review of expert knowledge use for mapping ecosystem services. Ecological Modelling, 295, 21-30

Labiosa, W.B., Forney, W.M., Esnard, A.M., Mitsova-Boneva, D., Bernknopf , R., Hearn, P., Hogan, D., Pearlstine, L., Strong e, D., Gladwin, H., \& Swain, E. (2013). An integrated multi-criteria scenario evaluation web tool for participatory land-use planning in urbanized areas: The Ecosystem Portfolio Model. Environmental Modelling \& Software, 41, pp.210-222

MA (Millennium Ecosystem Assessment) 2005. Ecosystems and Human Well-being: Synthesis. Island Press, Washington, D.C.

Maes, J., Egoh, B., Willemen, L., Liquete, C., Vihervaara, P., Schägner, J.P., Grizzetti, B., Drakou, E.G., LaNotte, A., Zulian, G., Bouraoui, F., Paracchini, M.L., Braat, L., \& Bidoglio, G., (2012). Mapping ecosystem services for policy support and decisionmaking in the European Union. Ecosystem Services, 1, 31-39.

Saeima of the Republic of Latvia (2010). Sustainable Development Strategy of Latvia until 2030, Riga

Saeima of the Republic of Latvia. (2012). National Development Plan of Latvia for 20142020, Riga

Scholz, R.W. (2011). Environmental Literacy in Science and Society: From Knowledge to Decisions. Cambridge University Press, Cambridge.

Seppelt, R., Dormann, C.F., Eppink, F.V., Lautenbach, S., \& Schmidt, S. (2011). A quantitative review of ecosystem service studies: approaches, shortcomings and the road ahead. Journal of Applied Ecology, 48 (3), 630-636.

Tansley, A.G. (1935). The use and abuse of vegetation terms and concepts. Ecology 16 (3), 284-307.

TEEB, (2010). The economics of ecosystems and biodiversity: mainstreaming the economics of nature: a synthesis of the approach, conclusions and recommendations of TEEB.

Terrado, M., Acuna, V., Ennaanay, D., Tallis, H., \& Sabater, S. (2014). Impact of climateextremes on hydrological ecosystem services in a heavily humanized Mediterranean basin. Ecological Indicators, 37, 199-209. 